\title{
Self-healing of Poly(2-hydroxyethyl methacrylate) Hydrogel through Molecular Diffusion
}

(Swa-Pemulihan Hidrogel Poli(2-hidroksietil metakrilat) melalui Penyusupan Rawak Molekul)

\author{
N.A. SIRAJUDDIN \& M.S. MD JAMIL*
}

\begin{abstract}
Synthetic materials that are capable of healing upon damage are being developed at a rapid pace because of their many potential applications. Here, new healing chemically cross-linked hydrogel of poly(2-hydroxyethyl methacrylate) ( diffusion of dangling chain and the chain slippage led to healing of the gel. The peaks in attenuated total reflectance (ATR) confirmed that hydrogel was formed while rheological studies had determined the minimum for healing temperature is $48.5^{\circ} \mathrm{C}$. The results showed that ratio stress of the healable hydrogel can reach until 92 and $91 \%$ of first and second healing cycle, respectively. The morphology of the sample was carried out to evaluate the self-property of hydrogel.
\end{abstract}

Keywords: Chain slippage; intermolecular diffusion; self-healing hydrogel; temperature

ABSTRAK

Keupayaan swa-pemulihan pada bahan sintetik banyak digunakan dalam aplikasi perubatan serta aplikasi-aplikasi yang berkaitan. Suatu hidrogel baharu iaitu poli(hidrosietil metakrilat) telah disediakan melalui tindak balas kimia. Swa-pemulihan hidrogel berlaku apabila diberikan haba melebihi suhu peralihan kaca (Tg) dan gel yang telah dipotong bercantum semula melalui proses penyusupan rawak molekul dan penggelinciran rantai. Puncak spektrum yang ditunjukkan dalam ATR mengesahkan proses taut silang yang berlaku dalam hidrogel tersebut. Suhu pemulihan minimum pula telah ditentukan oleh kajian reologi. Hasil ujian tensil membuktikan kekuatan hidrogel pemulihan berupaya mencapai sehingga $92 \%$ pada kitaran pertama dan 91\% pada kitaran kedua. Ujian morfologi telah dijalankan bagi mengenal pasti sifat pemulihan hidrogel tersebut.

Kata kunci: Penggelinciran rantai; penyusupan molekul; suhu; swa-pemulihan hidrogel

\section{INTRODUCTION}

Self-healing materials possess the ability to repair themselves in response to damage leading to a new route towards safer, longer-lasting products (Blaiszik et al. 2010; Dohler et al. 2013). In recent years there is fast growing interest on a variety of self-healing polymers (Chen et al. 2012; Maes et al. 2012; Murphy \& Wudl 2010). Selfhealing mechanism in bulk polymer materials are either based on release of repair agents upon damage (Lee et al. 2011) or on the inclusion of latent molecular functionalities in the polymer structure that trigger repair via thermally reversible reactions, hydrogen bonding, ionomeric arrangements, or molecular diffusion and entanglement (Bergman \& Wudl. 2008; Billiet et al. 2013). Of them, self-healing hydrogel has attracted much attention due to their great potential in biomedical applications (Deng et al. 2012; Phadke et al. 2012).

During repair, physical or chemical damage often will cause chain ruptures, resulting in reactive chain ends that significantly contribute to self-healing. Assuming bond cleavage does not occur during damage, chain or intermolecular diffusion is one of the driving forces for self-repairing of polymeric materials and the source of loose chain ends is chain slippage. It is noticed that many self-healing hydrogels are stimuli-healable hydrogels because their repairing process requires the input of a stimulus to be activated (Deng et al. 2012; Phadke et al. 2012; Tang et al. 2007).

It has also been reported that crack healing takes place in polymer matrix when a damaged material is annealed above the glass transition temperature where 'intermolecular diffusion' of dangling chain at interface occurs henceforth leading to entanglement couplings (Dohler et al.2013; Wool 1994). The healing behaviour is accelerated at higher temperature because of the enhanced intermolecular diffusion of dangling chain at interface. Not only a single crack but also mechanically induced damages such as crazes and micro-voids are also healed by means of chain inter-diffusion above $\mathrm{T}_{\mathrm{g}}$ for various polymers including semi-crystalline polymers such as polyethylene and polypropylene (Begley et al.2008; Yajuan et al. 2012). Further, the 'dangling chains' in the gel, defined as the chain segments whose one end is not connected to the network, are responsible for repairing nature, because the dangling chains exhibit segmental interdiffusion like liquid at a local scale (Radi et al. 2013; Yamaguchi et al. 2009). 
Here, we report the discovery of self-healing poly(2hydroxyethyl methacrylate) (pHEMA) hydrogel prepared with chemically cross-linked conditions at temperatures above minimum healing temperature, exhibiting both good self-healing capability and mechanical strength. This finding is important because pHEMA hydrogel has been extensively studied and considered as one of the hydrogels most suitable for biomedical and tissue engineering applications.

\section{EXPERIMENTAL DETAILS}

\section{MATERIALS}

Monomer 2-hydroxyethyl methacrylate (HEMA) with $\mathrm{M}_{\mathrm{w}}$ $130.14 \mathrm{~g} / \mathrm{mol}$, potassium persulfate, (KPS ACS reagent with $\mathrm{M}_{\mathrm{w}} 270.32 \mathrm{~g} / \mathrm{mol}$ ), L-cystine (with $\mathrm{M}_{\mathrm{w}} 240.30 \mathrm{~g} / \mathrm{mol}$ ) and solvent dimethyl sulfoxide (DMSO with molecular weight $78.13 \mathrm{~g} / \mathrm{mol}$ ) were purchased from Sigma Aldrich (Malaysia). All chemicals were used as received.

\section{HYDROGEL PREPARATION}

The stock solutions were prepared using the following concentrations: KPS in water $(0.00012 \mathrm{mg} / 5 \mathrm{~mL}), \mathrm{L}$-cystine in DMSO (0.0004 mg/40 mL) and HEMA (4 M). The hydrogel without dye were prepared in aqueous solutions at $22^{\circ} \mathrm{C}$ in the presence of $0.09 \mathrm{M}$ KPS initiator, $4 \mathrm{M}$ HEMA monomer and $0.04 \mathrm{M}$ L-cystine cross-linker. In another beaker, the hydrogel with dye was prepared exactly similar to the procedure before (Belma 2000; Zhao et al. 2012). Using Rhodamine B as dye, the diffusion can be more clearly seen. After mixed up all the materials above, the dye $(0.02 \mathrm{~g} / 3 \mathrm{~mL})$ was added and allowed the mixture solution to be stirred for a while. Then, the reaction was carried out in the beaker and the solution was then poured into a petri dish. The polymerization was conducted at $45^{\circ} \mathrm{C}$ for $5 \mathrm{~h}$.

\section{HEALING PROCEDURE}

The gel was cut into two pieces using scissors and two halves from each of the original hydrogels were put together rapidly to have their freshly created fracture surfaces brought into contact at $60^{\circ} \mathrm{C}$ for $5 \mathrm{~h}$. These healing procedure experiments were totally done in the same size of petri dish.

\section{MECHANICAL MEASUREMENT}

The dried gel was cut into dumbbell shape and was tested with Testometric M500-50CT Universal Testing Machine. Tensile test were performed on gel before and after healing condition. The load cell used was $10 \mathrm{kN}$ with speed 15 $\mathrm{mm} / \mathrm{min}$. This mechanical testing was done on 5 samples for each condition. Dimension with all length ratios used confirm to the standard of American Society for Testing and Materials (ASTM D5045-99 2007). In order to evaluate the healing behaviour quantitatively, healing efficiency can be expressed as the percentage ratio of ultimate tensile strength, $R(\sigma)$, before $\left(\sigma_{\text {initial }}\right)$ and after healing $\left(\sigma_{\text {healed }}\right)$ as shown in (1) (Yamaguchi et al. 2009).

$$
R(\sigma)=\frac{\sigma_{\text {healead }}}{\sigma_{\text {initial }}} \times 100
$$

\section{CHARACTERIZATION OF THE GEL BY ATTENUATED TOTAL REFLECTANCE (ATR)}

ATR spectra of pure HEMA, gel before healing and after healing were recorded with Spectrum ASCII PEDS 400 ATR Spectrometer to carry out the spectral analysis. The gel first was cut into cubic shape and dried in the oven and then only was sent to the analysis. All spectra were recorded at room temperature within range $4000-650 \mathrm{~cm}^{-1}$.

\section{RHEOLOGICAL MEASUREMENT}

The temperature sweep measurement were performed on Anton Paar Rheoplus/32 Rheometer with oscillatory measurements at $1 \mathrm{~Hz}$, while the temperature was increased at the rate of $5^{\circ} \mathrm{C} / \mathrm{min}$ between 25 and $180^{\circ} \mathrm{C}$ and the thickness dimension used was $1 \mathrm{~mm}$.

\section{MORPHOLOGICAL OBSERVATION}

Photographs showing the self-healing of pHEMA hydrogel were taken in transmitted light and under UV lamp.

\section{RESULTS AND DISCUSSION}

A self-healing system in hydrogel materials was achieved by reptation of dangling side chains (or chain slippage) through the network to the damage area for healing recovery (Yamaguchi et al. 2009). This system based on cross-linked hydrogel of poly(2-hydroxyethyl methacrylate) was prepared.

\section{PROPOSED MECHANISM OF 2-HYDROXYETHYL} METHACRYLATE HYDROGEL

Scheme 1 represents the proposed mechanism of pHEMA hydrogel by free radical polymerization. Mechanism that we have proposed below shows two possible reactions. The radical that produced from initiator will attack the $\mathrm{C}=\mathrm{C}$ of monomer. Therefore, once polymerization completed, spectrum for $\mathrm{C}=\mathrm{C}$ at $1637 \mathrm{~cm}^{-1}$ (Figure 1(a)) will disappear as shown in the ATR spectra (Figure 1(c)). Besides, the second possible reaction is condensation process between hydroxyl group of the HEMA with carboxylic acid of the cystine forming ester bond which it is in agreement with the previous study reported (Bhalekar et al. 2013). In addition, the elements for breaking and reformation of disulphide bond on the hydrogel for thermally healing system will be explored in the future.

The ATR spectra of pure monomer, L-cystine and pHEMA hydrogel; before and after healing condition are shown in Figure 1. Peak $1637 \mathrm{~cm}^{-1}$ (in Figure 1(a)) which corresponds to $\mathrm{C}=\mathrm{C}$ stretch for pure monomer was 

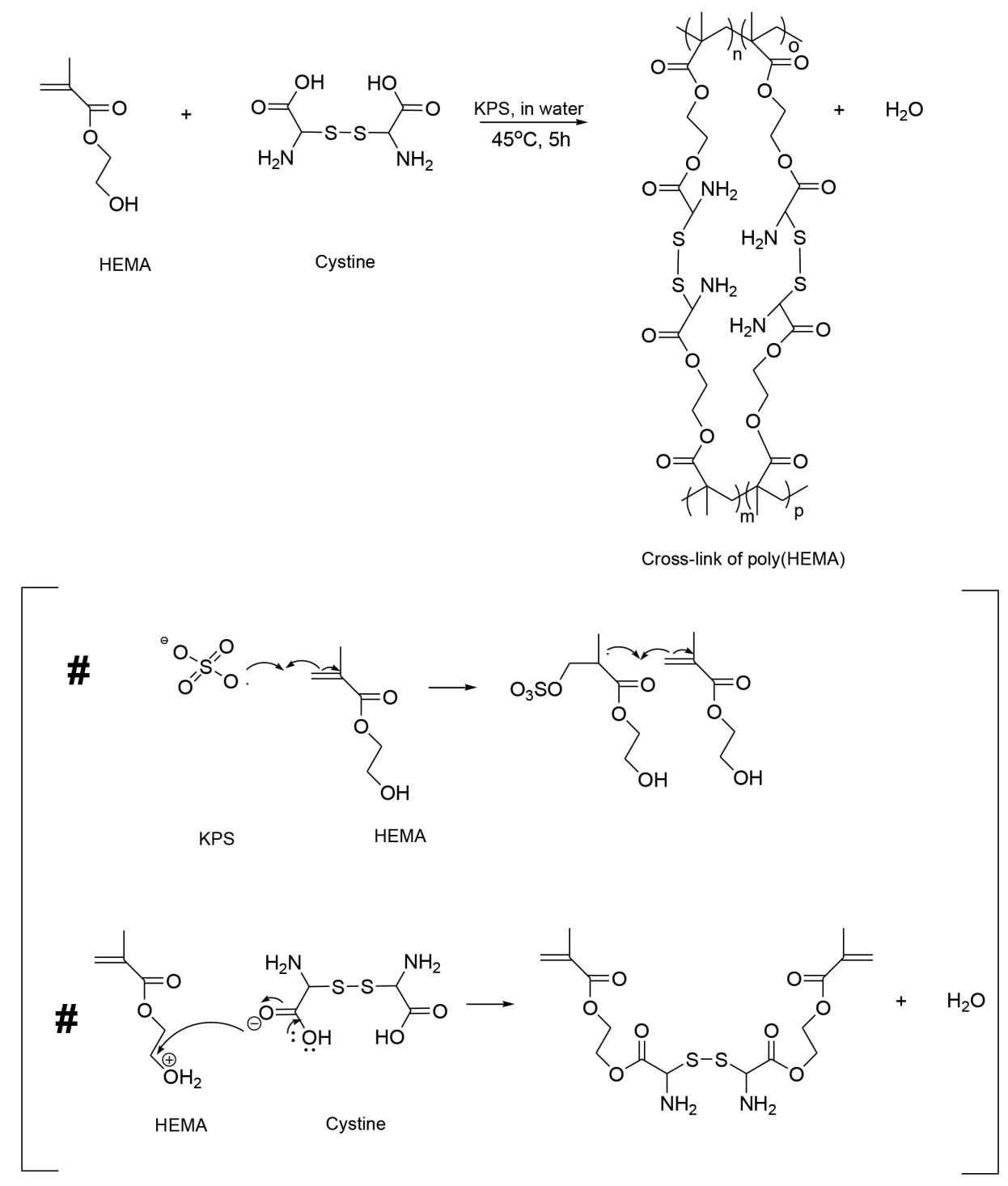

SCHEME 1. Proposed mechanism of poly(HEMA) hydrogel

invisible after the hydrogel was formed (Figure 1(c)). The stretching vibration band of $\mathrm{C}=\mathrm{O}$ was observed at $1718 \mathrm{~cm}^{-1}$; the characteristic absorption band of C-O was observed at $1155 \mathrm{~cm}^{-1}$; the distortion vibration bands of methyl and methylene were observed at 1275, 1246 and $1017 \mathrm{~cm}^{-1}$ (Zhang et al. 2014). Besides, spectrum for gel after healing condition (Figure 1(d)) was seen to have no difference with gel before healing condition (Figure 1(c)) and this indicates that the chemical structure of the gel remained the same.

\section{RHEOLOGICAL STUDY OF PHEMA HYDROGEL}

The formation of pHEMA hydrogel was further investigated with rheological properties. Figure 2 shows the curve of storage modulus G' and loss modulus G' of the gel at increased temperatures before and after healing condition. In our work, the storage modulus decreases with temperature for both samples and remains a constant value at high temperature, which is known plateau modulus. This is attributed to the existence of a permanent network, prohibiting the macroscopic flow (Yamaguchi et al. 2009). In agreement with ATR results, this shows that the present hydrogel system displays a predominantly solid-like behaviour. As known, the storage modulus can be used to measure the extent of gel network formation. Note that cross-linked polymers do not 'flow' because the entanglements are chemical covalent links and therefore they have a rubbery plateau up to the decomposition temperature (Ferry 1980; Lesueur 2009) as shown in Figure 2. Both storage $\left(G^{\prime}\right)$ and loss modulus $\left(G^{\prime \prime}\right)$ decrease with an increase of the gel temperature $\left(45^{\circ} \mathrm{C}\right)$ indicates that the molecules had started to vibrate until the point where the rubbery plateau was constant and stabilize. At this point, the molecules are 'free' and the reptation process begins which contributed to the healing process. In comparison with G', the higher G' value of the gel means the stronger gel intensity (Tang et al. 2007). 


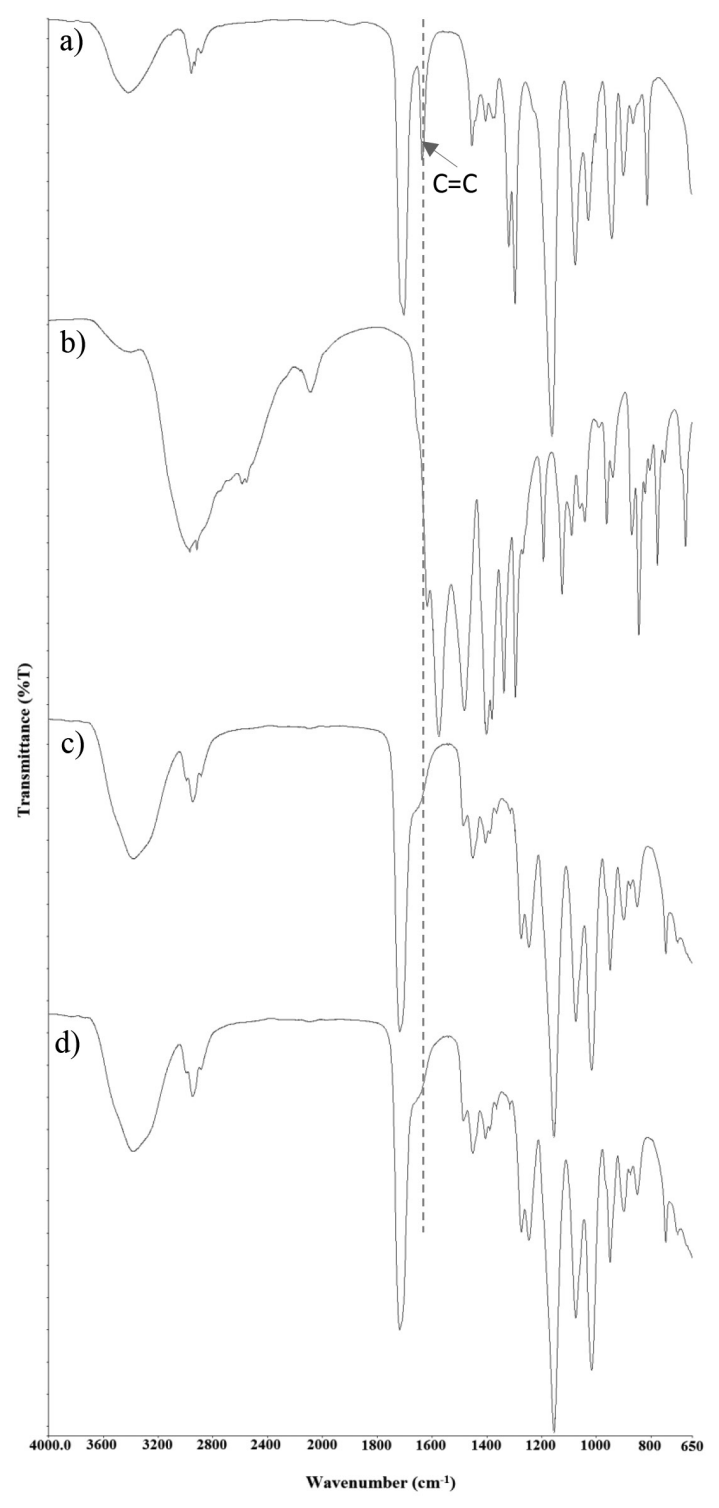

FIGURE 1. ATR spectra in the region 4000-650 $\mathrm{cm}^{-1}$ recorded at room temperature of a) 2-hydroxyethyl methacrylate, b)

L-cystine, c) gel before healing and d) gel after healing
Besides, we can also determine the minimum healing temperature used in the experiment (Lesueur 2009). From the graph, the minimum healing temperature is shown to be around $48.5^{\circ} \mathrm{C}$ (Figure 2(b)) to $49^{\circ} \mathrm{C}$ (Figure 2(a)). Since the healing process known to start at $48.5^{\circ} \mathrm{C}$, thus the healing temperature used in this experiment which at $60^{\circ} \mathrm{C}$ is adequate to trigger the molecular for reptation and diffusing to the affected area. In addition, the little difference between the transition temperature before and after healing may suggest that there is no further curing or crosslinking in the sample. Instead, the healing process might occur due to the chain slippage and intermolecular diffusion of dangling chain (Dohler et al. 2013; Moura et al. 2007).

\section{THE HEALING EFFICIENCY OF SELF-HEALING HYDROGEL}

The self-repairing property is evaluated quantitatively by tensile testing employing repaired samples by the buttjoint technique at the cut surface (ASTM D5045-99 2007). The stress-strain curves of different conditions or cycle hydrogel were obtained as shown in Figure 3.

From Table 1, we can see the pattern of healing in hydrogel. The healing efficacy of hydrogel decreased as the number of cycle increased. Nevertheless, the percentage of healing was still considered relatively high due to little difference between them and the original sample. In the first and second healing cycle, the healing percentages are 92 and $91 \%$, respectively. These percentages of healing indicate that the strength of this poly(HEMA) hydrogel is considerable (Deng et al. 2012).

Again, this might be due to the intermolecular diffusion and chain slippage of entanglement chain during healing process. Healing recovery has been shown to achieve by rearranging polymer chains at ambient or elevated temperatures. According to Wool's (2008, 1993) theory, the crack healing via molecular inter-diffusion in polymeric material involves the process of surface rearrangement, wetting, diffusion and randomization that takes place across the micro-fine crack. In similar concept,
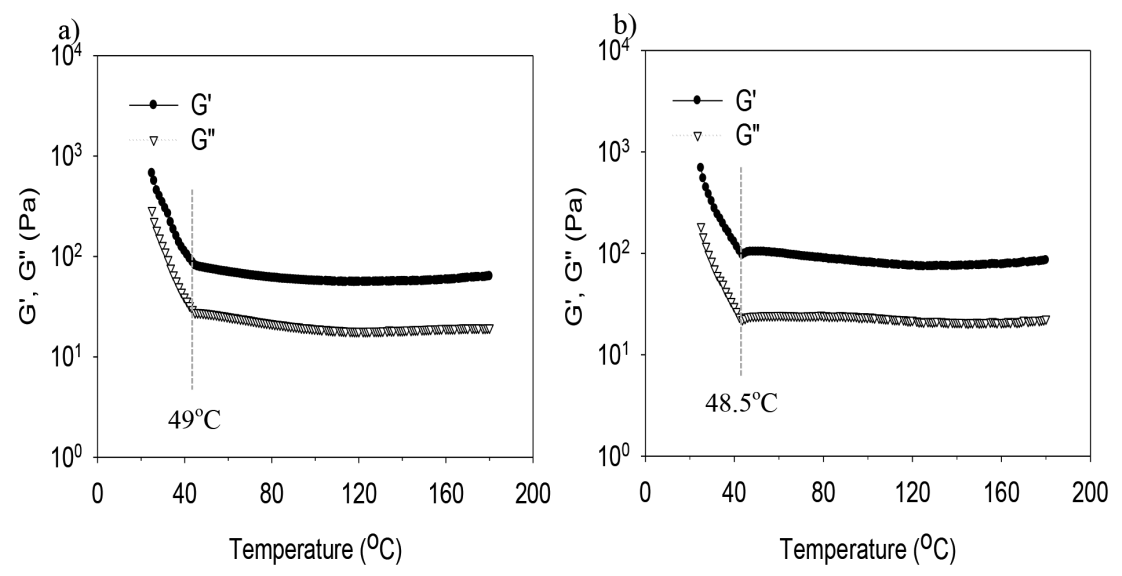

FIGURE 2. Temperature dependence of storage modulus G' and loss modulus G" of a) gel before and b) after healing at a heating rate $5^{\circ} \mathrm{C} / \mathrm{min}$ 
Wool and O'Connor (1983) proposed a reptation mode; in which an interface between the fracture surfaces was formed by random walk chains or moving polymer that from a tube-like region and diffusion by reptation across a polymer-polymer weld line before the chains form new physical crosslinks (Pavlos 2010). The crack healing process was described schematically as shown in Figure 4 (Dohler et al. 2013).

\section{MORPHOLOGICAL OBSERVATION OF PHEMA HYDROGEL}

This 'healing capability' of the self-healing hydrogel was further verified using optical microscopy. Figure 5

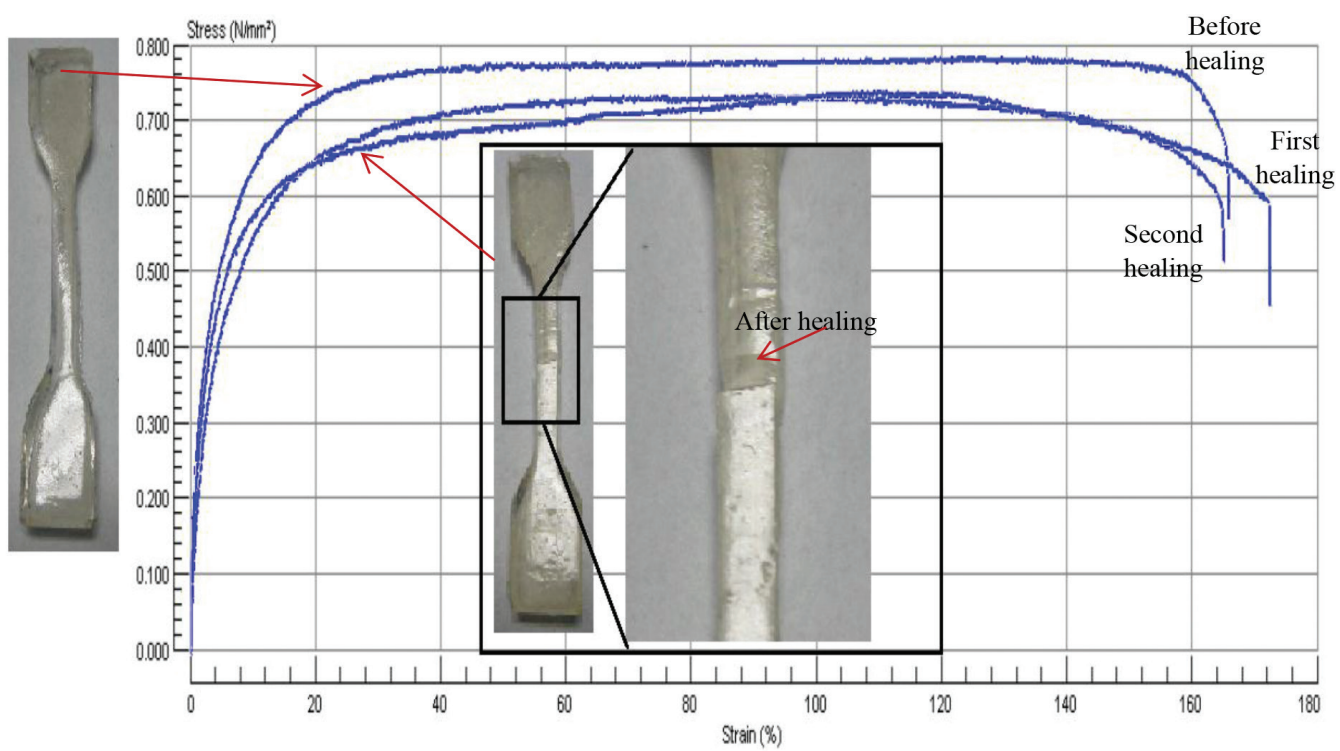

FIGURE 3. Stress-strain curves of sample before healing, first and second healing

TABLE 1. The percentage of ratio stress at before and healable hydrogel condition

\begin{tabular}{lcc}
\hline Cycle & $\begin{array}{c}\text { Ultimate tensile stress } \\
\left(\mathrm{N} / \mathrm{mm}^{2}\right)\end{array}$ & $R(\sigma)=\frac{\sigma_{\text {healead }}}{\sigma_{\text {initial }}} \times 100$ \\
\hline Before healing & 0.7800 .20 & $100 \%$ \\
First healing & 0.7200 .10 & $92 \%$ \\
Second healing & 0.7100 .20 & $91 \%$ \\
\hline
\end{tabular}

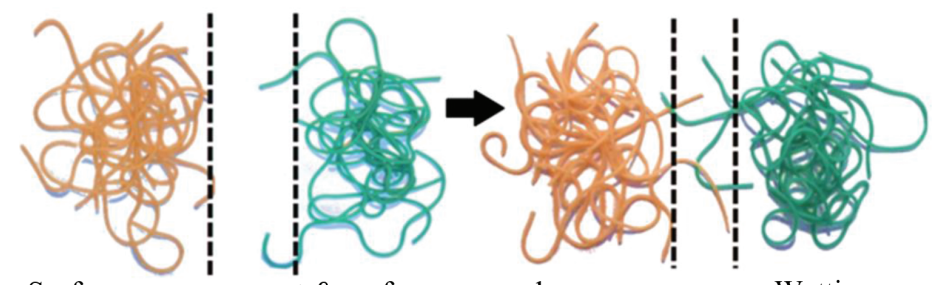

Surface rearrangement $\&$ surface approach Wetting

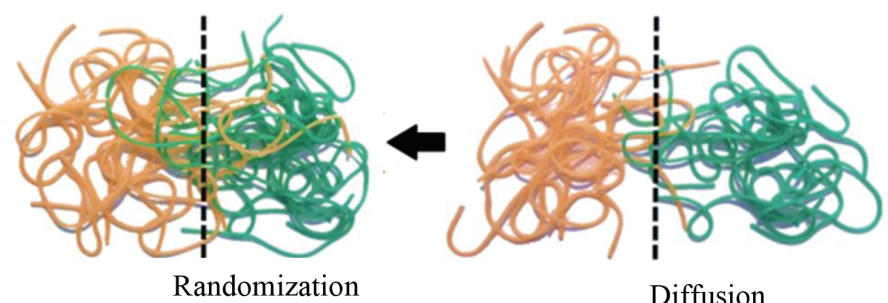

FIGURE 4. Schematic of self-healing mechanism of the self-healing hydrogel (Dohler et al. 2013) 

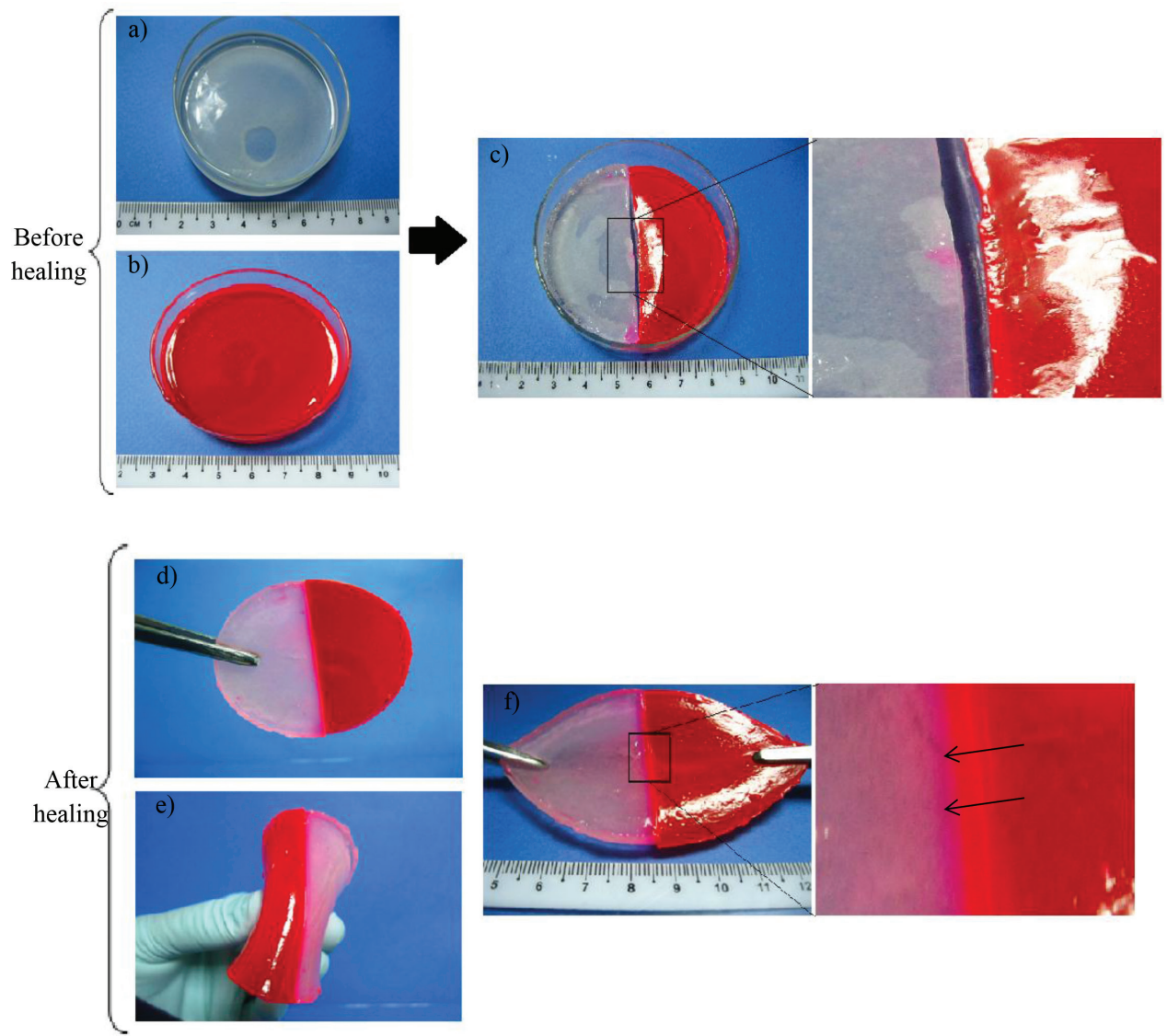

FIGURE 5. Photograph of the hydrogel before and after healing process; a) Hydrogel without dye, b) Hydrogel with Rhodamine B dye and c) the cut sample brings into contact. Hydrogel still d) merged together when e) bending forces and f) stretching forces were given to the healable hydrogel
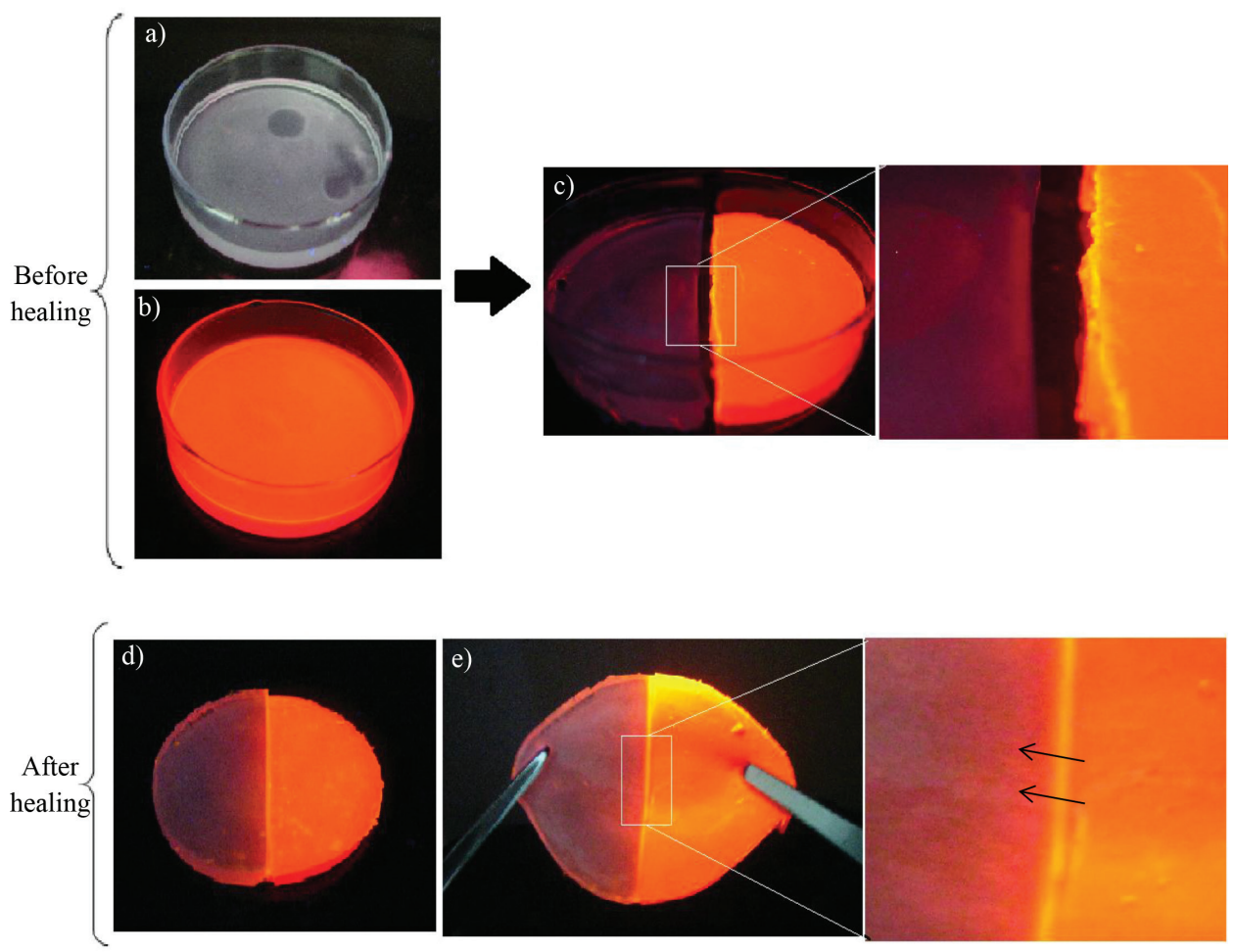

FIGURE 6. Photograph before and after healing process under UV lamp a) Hydrogel without dye, b) Hydrogel with Rhodamine B, c) Hydrogel after being cut, d) Hydrogel after merged together and e) when stretching forces were applied 
shows characteristics optical micrographs of the healable hydrogel. The cut region is clearly seen (Figure 5(a)-5(c)) and after healing at $60^{\circ} \mathrm{C}$ for $5 \mathrm{~h}$, this cut is apparently healed; in which the cut surface was filled up and brought into contact (Figure 5(d)). The self-healed, one-piece hydrogel could withstand several kinds of mechanical forces without failure at the interface, such as bending and stretching to a large extension (Figure 5(e)-5(f)).

Other than camera, the photos were also taken under UV lamp (Figure 6(a)-6(e)). UV lamp was used to enhance the fluorescence characteristics so that the diffusion would be clearly seen. The steps in UV lamp mode were the same as in the transmitted light mode; i.e. freshly prepared hydrogel without dye (Figure 6(a)) and hydrogel with dye, Rhodamine B (Figure 6(b)). The samples were cut and brought into contact (Figure 6(c)). Moreover, under UV lamp, we can emphasise the intermolecular diffusion due to the healing process when the healable hydrogel (Figure 6(d)) is applied as stretching forces (Figure 6(e)).

\section{CONCLUSION}

In summary, chemically cross-linked poly(HEMA) hydrogel prepared using the free radical polymerization method can self-heal at given temperature. The self-healable hydrogel is mechanically strong and this is exhibited by the highest fracture stress reported so far. Our study suggested that intermolecular diffusion of dangling chain contributed to this self-healing of hydrogel. Moreover, chain slippage might have occurred and caused the pHEMA hydrogel to become healable. This discovery is important because pHEMA hydrogel is economical, easy to produce and has great potential for biomedical applications due to its biocompatibility and nontoxicity. The discovery of selfhealing ability adds a new value to this old hydrogel.

\section{ACKNOWLEDGEMENTS}

The authors acknowledge the financial support of this study by Government of Malaysia through FRGS/1/2012/ SE07/UKM/03/1, GGPM-2012-014 and ERGS/1/2012/TK04/ $\mathrm{UKM} / 03 / 3$ grants. The authors also wish to thank the School of Chemical Sciences and Food Technology and School of Materials Science and Applied Physics of Universiti Kebangsaan Malaysia for the continuous support of this project.

\section{REFERENCES}

ASTM D5045-99. 2007. Standard Test Methods for Plane-strain Fracture Toughness and Strain Energy Release Rate of Plastic Materials. American Society for Testing and Materials.

Begley, T.H., Brandsch, J., Limm, W., Siebert, H. \& Piringer, O. 2008. Diffusion behaviour of additives in polypropylene in correlation with polymer properties. Food Additives \& Contaminants Part A, Chemistry, Analysis, Control, Exposure \& Risk Assessment 25(11): 1409-1415.

Belma, ISIK. 2000. Swelling behaviour of acrylamide-2hydroxyethyl methacrylate hydrogels. Turkish Journal of Chemistry 24: 147-156.
Bergman, S.D. \& Wudl, F. 2008. Mendable polymers. Journal of Materials Chemistry 18: 41-62.

Bhalekar, M., Sonawane, S. \& Shimpi, S. 2013. Synthesis and characterization of a cysteine xyloglucan as mucoadhesive polymer. Brazilian Journal of Pharmaceutical Science 49(2): 285-292.

Blaiszik, B.J., Kramer, S.L.B., Olugebefola, S.C., Moore, J.S., Sottos, N.R. \& White, S.R. 2010. Self-healing polymer and composite - Autonomous materials systems. Annual Review of Materials Research 40: 179-211.

Billiet, S., Hillewaere, X.K., Teixeira, R.F. \& Du Prez, F.E. 2013. Chemistry of crosslinking processes for self-healing polymers. Macromolecular Rapid Communications 34(4): 290-309.

Chen, Y., Kushner, A.M., Williams, G.A. \& Guan, Z. 2012. Multiphase design of autonomic self-healing thermoplastic elastomers. Nature Chemistry 4: 467-472.

Deng, G., Li, F., Yu, H., Liu, F., Liu, C., Sun, W., Jiang, H. \& Chen, Y. 2012. Dynamic hydrogels with an environmental adaptive self-healing ability and dual responsive sol-gel transitions. ACS Macro Letters 1: 275-279.

Dohler, D., Michael, P. \& Binder, W. 2013. Principles of selfhealing polymers. In Self-Healing Polymers: From Principles to Applications, edited by Binder, W.H. New York: WileyVCHVerlag GmbH \& Co. KGaA. pp. 5-60.

Ferry, J.D. 1980. The colloidal structure of bitumen: Consequences on the rheology and on the mechanisms of bitumen modification. In Viscoelastic Properties of Polymers. 3rd ed. New York: Wiley \& Sons.

Lee, J., Bhattacharyya, D., Zhang, M.Q. \& Yuan, Y.C. 2011. Fracture behaviour of a self-healing microcapsule-loaded epoxy system. Express Polymer Letters 5(3): 246-253.

Lesueur, D. 2009. The colloidal structure of bitumen: Consequences on the rheology and on the mechanisms of bitumen modification. Advances in Colloid and Interface Science 145: 42-82.

Maes, F., Montarnal, D., Cantournet, S., Tournilhac, F., Corte, L. \& Leibler, L. 2012. Activation and deactivation of selfhealing in supramolecular rubbers. Soft Material 8: 16811687.

Moura, M.J., Figueiredo, M.M. \& Gil, M.H. 2007. Rheological study of genipin cross-linked chitosan hydrogels. Biomacromolecules 8: 3823-3829.

Murphy, E.B. \& Wudl, F. 2010. The world of smart healable materials. Progress in Polymer Science 35: 223-251.

Pavlos, S., Stephanoul, Chunggi, B., Georgia, T., Vlasis, G.M. \& Martin, K. 2010. Quantifying chain reptation in entangled polymer melts: Topological and dynamical mapping of atomistic simulation results onto the tube model. Journal of Chemical Physics 132(12): 1-16.

Phadke, A., Zhang, C., Arman, B., Hsu, C.C., Mashelkar, R.A., Lele,A.K., Tauber, M.J.,Arya, G. \& Varghese, S. 2012. Rapid self-healing hydrogels. Proceeding of the National Academy Science of U.S.A. 109: 4383-4388.

Radi, B., Wellard, R.M. \& George, G.A. 2013.Effect of dangling chains on the structure and physical properties of a tightly crosslinked poly(ethylene glycol) network. Soft Material 9: 3262-3271.

Tang, Y.F., Du, Y.M., Hu, X.W., Shi, X.W. \& Kennedy, J.F. 2007. Rheological characterization of a novel thermo-sensitive chitosan/poly(vinyl alcohol) blend hydrogel. Carbohydrate Polymers 67: 491-499. 
Wool, R.P. 2008. Self-healing materials: A review. Soft Material 4(3): 400-418.

Wool, R.P. 1994. Polymer Interfaces: Structure and Strength. Cincinnati, New York: Hanser Gardner. pp. 445-479.

Wool, R.P. 1993. Polymer Entanglements. Macromolecules 26: 1564-1569.

Wool, R. \& O'Connor, K. 1983. Theory of crack healing in polymers. Journal of Applied Physics 52(10): 5953-5963.

Yamaguchi, M., Ono, S. \& Okamoto, K. 2009. Interdiffusion of dangling chains in weak gel and its application to selfrepairing material. Materials Science Engineering B 162(3): 189-194.

Yajuan, Y., Qingzhi, L., Lianying, W. \& Yangdong, H. 2012. Molecular dynamics simulation for diffusion of organic molecules in polyethylene membranes. Journal CIESC 63(1): 113-113.

Zhang, L., Zheng, G.J., Guo, Y.T., Zhou, L., Du, J. \& He, H. 2014. Preparation of novel biodegradable pHEMA hydrogel for a tissue engineering scaffold by microwave-assisted polymerization. Asian Pacific Journal of Tropical Medicine 136-140.
Zhao, Y., Gao, S., Zhao, S., Li, Y., Cheng, L., Li, J. \& Yin, Y. 2012. Synthesis and characterization of disulfidecrosslinked alginate hydrogel scaffolds. Materials Science and Engineering $C$ 32: 2153-2162.

Faculty of Science and Technology

Universiti Kebangsaan Malaysia

43600 Bangi, Selangor Darul Ehsan

Malaysia

*Corresponding author; email: suzeren@ukm.edu.my

Received: 15 January 2014

Accepted: 15 November 2014 